\title{
Respon Pemberian Macam Dosis Dan Interval Waktu Apliksasi Trichoderma sp. Terhadap Produksi Tanaman Kedelai (Glycine Max L.)
}

\section{Response of Various Trichoderma sp. Dosing and Application Time Intervals on Production of Soybean (Glycine Max L.)}

\author{
Robi Ardiansah, Ana Amiroh dan M. Imam Aminuddin \\ Fakultas Pertanian Universitas Islam Darul ‘Ulum Lamongan Jawa Timur \\ Korespondensi : robiardiansyah069@gmail.com, Anaamiroh@unisda.ac.id
}

\begin{abstract}
ABSTRAK
Penelitian ini dilakukan di Desa Sukodadi, Kecamatan Sukodadi, Kabupaten Lamongan. Ketinggian tempat $\pm 5 \mathrm{mdpl}$. Waktu pelaksanaan penelitian dilakukan pada bulan Maret sampai Mei 2020. Penelitian ini menggunakan Rancangan Acak Kelompok (RAK) Faktorial, yang terdiri dari dua faktor dan setiap faktor terdiri dari 3 level yaitu : macam dosis dan interval waktu aplikasi Trichoderma sp. Faktor pertama, macam macam dosis terdiri dari3 level yaitu 0 mg/tanaman (kontrol), dosis $20 \mathrm{mg} /$ tanaman, $40 \mathrm{mg} /$ tanaman. Faktor kedua, interval waktu aplikasi yang terdiri dari 3 level yaitu interval 5 hari sekali, 10 hari sekali, 15 hari sekali. Indikator pertumbuhan dan produksi yang diamati terdiri dari : tinggi tanaman, jumlah daun, berat brangkasan basah, berat brangkasan kering, berat biji per petak, berat 1000 biji. Waktu pengamatan dilaksanakan mulai umur 14 hari dengan interval 10 hari sekali. Data hasil dari penelitian dianalisa menggunakan analisa sidik ragam dan dilanjutkan dengan Uji BNT 5\%. Hasil pengamatan dan perhitungan melalui analisa sidik ragam dapat diambil simpulan bahwa terdapat interaksi antara perlakuan dosis Trichoderma sp. $40 \mathrm{mg} /$ tanaman dan interval waktu aplikasi 15 hari sekali terhadap produksi tanaman kedelai. Menunjukan pengaruh nyata terhadap semua parameter pengamatan. Terdapat beda sangat nyata pada pengamatan tinggi tanaman, jumlah daun, berat brangkasan basah, berat brangkasan kering dan berat biji per petak. Terdapat tidak beda nyata pada pengamatan tinggi tanaman dan jumlah daun umur $14 \mathrm{hst}$.
\end{abstract}

Kata Kunci : Dosis, Interval waktu aplikasi, Trichoderma sp., Kedelai.

\section{ABSTRACT}

This research was conducted in Sukodadi Village, Sukodadi District, Lamongan Regency. Which has a place height of \pm 5 meters above sea level. The timing of the research was conducted from March to May 2020. This study used a factorial randomized block design (RBD), which consisted of two factors and each factor consisted of 3 levels, namely: various doses and time intervals for the application of Trichoderma sp. The first factor, the type of dosage consists of 3 levels, namely $0 \mathrm{mg}$ / plant (control), dose $20 \mathrm{mg}$ / plant, $40 \mathrm{mg}$ / plant. The second factor, the application time interval consisting of 3 levels, namely the interval of 5 days, 10 days, 15 days. The observed growth and production indicators consisted of: plant height, leaf number, wet stover weight, dry stover weight, seed weight per plot, 1000 seeds weight. Observation time was carried out starting at the age of 14 days with intervals of 10 days. The results data from the study were analyzed using variance analysis and followed by a 5\% LSD Test. The results of observations and calculations through analysis of variance can be concluded that there is an interaction between the treatment dose of 40 $\mathrm{mg} /$ plant and the application time interval of Trichoderma sp. once every 15 days on soybean plant production. Shows the real effect on all observed parameters There was a very significant difference in the observation of plant height, leaf number, wet stover weight, dry stover weight and seed weight per plot. There was no significant difference in the observations of plant height and number of leaves aged 14 days.

Keywords: Dosage, application time interval, Trichoderma sp. , soybeans. 


\section{PENDAHULUAN}

Kedelai (Glycine max L.) merupakan tanaman asli dari China dan telah menyebar ke beberapa negara seperti Jepang, Korea, India, Australia dan Amerika. Pada awal abad ke-16 tanaman ini dibawa ke Indonesia oleh pendatang dari China dan mulai dikenal oleh masyarakat khususnya di Pulau Jawa. (Marianah, 2013).

Selain padi dan jagung, kedelai juga merupakan tanaman pangan komoditas ketiga terpenting di dunia. Kedelai memiliki peran sebagai penyuplai protein nabati yang sangat penting dalam meningkatkan gizi masyarakat karena kedelai baik untuk kesehatan dan harganya yang relatif lebih ekonomis dibandingkan dengan sumber protein hewani. Dalam $100 \mathrm{gr}$ kedelai terkandung; $331.0 \mathrm{kkal}$ kalori $34.9 \mathrm{gr}$ protein, $18.1 \mathrm{gr}$ lemak, $34.8 \mathrm{gr}$ karbohidrat, $4.2 \mathrm{gr}$ serat, $227.0 \mathrm{mg}$ kalsium, $585.0 \mathrm{mg}$ fosfor, 8.0 $\mathrm{mg}$ besi, dan $1.0 \mathrm{mg}$ vitamin B1 (Bakhtiar et al., 2014).

Seiring dengan peningkatan jumlah popukasi penduduk kebutuhan kedelai terus mengalami peningkatan, namun kebutuhan kedelai di dalam negeri masih belum seimbang dengan kemampuan produksinya. Pada tahun 2016 ketersediaan kedelai di Indonesia masih sangat rendah, diperkirakan hanya sebanyak 926.000 ton, sedangkan perkiraan kebutuhan kedelai mencapai 2.235.000 ton (Badan Pusat Statistik, 2017). Menurut Neraca Kebutuhan dan Ketersediaan Pangan Tahun 2016 menyebutkan bahwa Indonesia impor kedelai hingga 2.000 ton. Hal tersebut mengharuskan Indonesia untuk memenuhi kebutuhan suplai kedelai dengan mengimpor $45 \%$ dari kebutuhan kedelai nasional (Mursidah, 2017). Penyebab berkurangnya areal tanam kedelai sebagai akibat minimnya partisipasi petani dalam menaman kedelai, karena budidaya kedelai belum mampu memberikan keuntungan yang minim pada petani. Pemupukan meruoakan salah satu faktor penting dalam meningkatkan produksi kedelai. Permasalahan sering terjadi dalam pemupukan adalah rendahnya efisiensi serapan unsur hara oleh tanaman. Upaya peningkatan efisiensi penggunaan pupuk dapat ditunjang melalui prinsip tepat sasaran, tepat dosis, tepat cara dan tepat waktu aplikasi serta sesuai takaran kebutuhan tanaman.

Strategi untuk meningkatkan produksi kedelai dapat dilakukan dengan berbagai cara. Salah satu di antaranya adalah penerapan jamur Trichoderma sp. yang dapat berfungsi sebagai agen hayati dan dapat membantu merangsang pertumbuhan tanaman. Akar tanaman kedelai akan lebih banyak akibat dari infeksi oleh jamur Trichoderma sp. berbeda dengan akar yang tidak diaplikasikan Trichoderma sp. Akar yang banyak mampu mendukung penyerapan unsur hara lebih optimal, sehingga pertumbuhan dan produktivitas tanaman dapat dengan maksimal. Jamur Trichoderma sp. juga dapat menguraikan nutrisi yang ada di dalam tanah, menghasilkan viridian dan antibiotik glikotoksin yang dapat digunakan untuk mencegah bibit tanaman dari penyakit serta mengeluarkan enzim $\beta$-1,3-glukanase dan kitinase yang berperan melarutkan dinding sel patogen (Ismail et al., 2011).

Trichoderma sp. merupakan jamur antagonis yang sering ditemukan di dalam tanah, khususnya pada tanah organik dan sering dipakai untuk pengendalian hayati, baik terhadap patogen tular tanah atau rizosfer maupun patogen filosfer. Sehingga struktur tanah akan menjadi lebih gembur, membuat akar dapat menyerap hara terutama posfat (P) dan mampu meningkatkan aktivitas mikroba di dalam tanah. Hubungan antara tanaman dengan Trichoderma sp. adalah bersifat mutualisme. Tanaman mendapat keuntungan dalam hal pertumbuhan maupun dalam pengendalian penyakit, sedangkan Trichoderma sp. diuntungkan karena mendapat nutrisi yang dihasilkan oleh tanaman.

Penelitian ini bertujuan untuk mengetahui berapa besar pengaruh dosis dan interval waktu aplikasi Trichoderma sp. terhadap produksi tanaman kedelai (Glycine $\max$

L.). 


\section{METODOLOGI PENELITIAN}

\section{Waktu dan Tempat}

Penelitian ini dilakukan di Desa Sukodadi, Kecamatan Sukodadi, Kabupaten Lamongan. Memiliki ketinggian tempat \pm 5 meter di atas permukaan laut. Waktu yang dilaksanakan pada bulan Maret sampai Mei 2020.

\section{Bahan dan Alat}

Bahan yang digunakan dalam penelitian ini adalah benih tanaman kedelai varietas Anjasmoro, jamur Trichoderma sp., pupuk gandasil B, pupuk NPK mutiara, Insektisida (Plenum), kompos dan air. Alat yang digunakan dalam penelitian ini adalah cangkul, sabit, penggaris, timbangan, papan nama, karung/glangsing, plastik kresek, alat tulis, gembor, timba, penyemprot dan alat penunjang lainnya.

\section{Metode Penelitian}

Penelitian ini menggunakan Rancangan Acak Kelompok (RAK) Faktorial, yang terdiri dari dua faktor dan setiap faktor terdiri dari 3 level yaitu : macam dosis dan interval waktu aplikasi jamur Trichoderma sp. Faktor pertama, macam dosis terdiri dari 3 level yaitu $0 \mathrm{mg} /$ tanaman (kontrol), $20 \mathrm{mg} /$ tanaman dan $40 \mathrm{mg} /$ tanaman. Faktor kedua, interval waktu aplikasi yang terdiri dari 3 level yaitu 5 hari sekali, 10 hari sekali, 15 hari sekali.

\section{Pelaksanaan penelitian}

\section{Pengolahan Tanah}

Pengolahan tanah diawali dengan pembersihan gulma yang ada di lahan. Selanjutnya dilakukan pembalikan atau penggemburan tanah dengan cara pembajakan atau mencangkul agar mudah untuk ditanami. Kemudian dilakukan pembuatan petakan dengan ukuran 1,5 $\times$ 1,5 meter.

\section{Penanaman}

Penanaman dilakukan seminggu setelah pengolahan lahan. Jarak tanam yang digunakan adalah $25 \times 25 \mathrm{~cm}$. Lubang tanam dibuat cara dengan ditugal dengan kedalaman $3 \mathrm{~cm}$. Pada setiap lubang tanam diisi 2 benih kedelai, kemudian ditutup dengan kompos.

\section{Pempukan}

Pemberian jamur Trichoderma sp. dilakukan dengan cara disiram atau sistem kocor pada area disekitar akar tanaman. Trichoderma sp. diberikan pada tanaman sesuai dengan interval waktu perlakuan yakni: 5 hari sekali, 10 hari sekali dan 15 hari sekali. Sedangkan untuk perlakuan dosisnya yakni: 0 $\mathrm{mg} /$ tanaman, $20 \mathrm{mg} /$ tanaman dan 40 $\mathrm{mg} /$ tanaman.

\section{Pemeliharaan Tanaman}

\section{Penyulaman}

Penyulaman dilakukan pada saat ada benih kedelai yang tidak tumbuh atau tumbuh dengan kondisi yang tidak sempurna. Penyulaman dilakukan dengan cara mengganti tanaman yang mati dengan tanaman yang tumbah normal dengan tinggi dan besar ukuran yang sama. Penyulaman ini dilakukan pada 7 hst dan dilakukan setiap 7 hari sekali.

\section{Penyiangan}

Penyiangan dilakukan dengan cara mencabut gulma yang tumbuh di sekitar kedelai di dalam petak baik secara manual dengan tangan maupun dengan bantuan alat lainnya. Penyiangan dilakukan setiap 15 hari sekali.

\section{Penyiraman}

Penyiangan dilakukan dengan cara mencabut gulma yang tumbuh di sekitar kedelai di dalam petak baik secara manual dengan tangan maupun dengan bantuan alat lainnya. Penyiangan dilakukan setiap 15 hari sekali.

\section{Penyiraman}

Penyiraman dilakukan jika hujan tidak turun, apabila terjadi hujan maka tidak dilakukan penyiraman. Penyiraman dilakukan dengan menggunakan gembor atau timba.

\section{Pengendalian OPT (Organisme Pengganggu Tanaman)}

Pengendalian hama dan penyakit dilakukan dengan cara pengendalian hama secara sistem terpadu. Pengendalian hama dan penyakit diberikan ketika beberapa dari tanaman telah terlihat mendapat serangan dari hama dan penyakit. 


\section{Pemanenan}

Pemanenan dilakukan ketika polong tanaman sudah mulai berwarna coklat dan terisi penuh serta daun sudah menguning dan berguguran. Pemanenan dilakukan dengan cara mencabut seluruh bagian tanaman kedelai sampai pada bagian akarnya.

\section{Pengeringan}

Pengeringan dilakukan dengan menjemur brangkasan basah di tempat yang kering dan mendapat paparan cahaya matahari secara langsung.

\section{Pemisahan Polong Dengan Kulitnya}

Polong kedelai dipisahkan dari kulitnya dengan cara ditumbuk, kemudian pemisahan antara biji dengan serbuk kulit yang dihasilkan dari proses penumbukan. Pemisahan dapat dilakukan dengan cara pengayakan dengan kawat jaring atau dengan kipas angin hingga biji terpisah dari serbuk kulit kedelai.

\section{Parameter Pengamatan}

Untuk mengetahui pengaruh dari masing-masing perlakuan dilakukan dengan cara pengamatan pada tiap tanaman sampel.
Pengamatan fase vegetatif dilakukan pada saat tanaman berumur 14 hari dengan interval 10 hari sekali. Adapun parameter yang diamati yaitu: parameter pertumbuhan (fase vegetatif) dan fase produksi (fase generatif).

\section{Pengamatan dan Pengolahan Data}

Indikator pertumbuhan dan produksi yang diamati meliputi : tinggi tanaman, jumlah daun, berat brangkasan basah, berat brangkasan kering, berat biji per petak dan berat 1000 biji. Pengamatan dilaksanakan mulai umur 14 hari dengan interval 10 hari sekali. Data hasil penelitian dianalisa menggunakan analisa sidik ragam dan kemudian dilanjutkan dengan Uji BNT 5\%.

\section{HASIL DAN PEMBAHASAN}

\section{Tinggi Tanaman}

Hasil analisa sidik ragam menunjukkan interaksi pada perlakuan macam dosis dan interval waktu aplikasi Trichoderma sp. terhadap pertumbuhan tinggi tanaman pada pengamatan umur 35 hst dan 45 hst. Selanjutnya dapat dilihat pada Tabel 1.

Tabel 1. Rata-rata tinggi tanaman (cm) Pada Umur 35 Hst dan 45 Hst.

\begin{tabular}{|c|c|c|}
\hline \multirow[t]{2}{*}{ Perlakuan } & \multicolumn{2}{|c|}{$\begin{array}{l}\text { Rata-rata tinggi tanaman }(\mathrm{cm}) \\
\text { pada pengamatan umur }\end{array}$} \\
\hline & 35 hst & 45 hst \\
\hline Dosis Trichoderma sp. 0 mg/tanaman + interval 5 hari & $42.6 \mathrm{~d}$ & $45,73 \mathrm{e}$ \\
\hline Dosis Trichoderma sp. 0 mg/tanaman + interval 10 hari & $42.5 \mathrm{~d}$ & 45,07 e \\
\hline Dosis Trichoderma sp. 0 mg/tanaman + interval 15 hari & $43.3 \mathrm{~d}$ & $46,20 \mathrm{de}$ \\
\hline Dosis Trichoderma sp. 20 mg/tanaman + interval 5 hari & $44.2 \mathrm{~d}$ & $48,20 \mathrm{c}$ \\
\hline Dosis Trichoderma sp. 20 mg/tanaman + interval 10 hari & $44.7 d$ & $49,73 \mathrm{bc}$ \\
\hline Dosis Trichoderma sp. 20 mg/tanaman + interval 15 hari & $47.7 \mathrm{c}$ & $48,03 \mathrm{~cd}$ \\
\hline Dosis Trichoderma sp. 40 mg/tanaman + interval 5 hari & $53.2 \mathrm{a}$ & 53,53 a \\
\hline Dosis Trichoderma sp. 40 mg/tanaman + interval 10 hari & $49.9 \mathrm{~b}$ & $50,07 \mathrm{~b}$ \\
\hline Dosis Trichoderma sp. 40 mg/tanaman + interval 15 hari & $50.6 \mathrm{~b}$ & $52,07 a$ \\
\hline BNT 5\% & 2,25 & 1,72 \\
\hline
\end{tabular}

Keterangan:Angka-angkayang diikutioleh hurufyang sama dalam kolom yang sama tidak berbeda nyata dengan uji BNT 5\%.

Pada Tabel 1, dapat dilihat bahwa pengamatan prameter tinggi tanaman pada umur 35 hst terdapat perbedaan sangat nyata dan pada umur 45 hst terdapat perbedaan nyata pada perlakuan macam dosis dan interval waktu aplikasi Trichoderma sp. dengan hasil terbaik pada perlakuan dosis $40 \mathrm{mg} /$ tanaman dengan interval waktu 5 hari. Hal ini karena jamur Trichoderma sp. yang diaplikasikan ke dalam tanah akan berasosiasi dengan akar tanaman dan menyelimuti akar yang kemudian masuk kedalam perakaran tanaman melalui rambut akar dan menginfeksi akar dengan cara masuk ke 
dalam bagian ujung akar dan menyebabkan selnya membentuk bintil sehingga jumlah sel di dalam bintil akar dapat meningkat. Akar yang terinfeksi Trichoderma sp. akan membentuk akar-akar cabang yang lebih banyak dibandingkan dengan akar yang tidak terinfeksi. Perakaran yang banyak tersebut mampu meningkatkan penyerapan unsur hara menjadi lebih baik, sehingga tanaman dapat tumbuh dengan maksimal.

Pemberian dosis yang berbeda pada setiap perlakuan meningkatkan penyerapan unsur hara berbeda karena hifa dari mikoriza dapat menghasilkan asam-asam organik dan enzim fosfatase yang akan mempercepat terbentuknya unsur $\mathrm{P}$ dan Trichoderma $\mathrm{sp}$. memudahkan pertumbuhan organ tanaman dan meningkatkan aktivitas biologis mikroorganisme di dalam tanah yang menguntungkan (Utomo, 2009). Trichoderma sp. secara tidak langsung mampu meningkatkan pertumbuhan tanaman yaitu dengan menekan patogen dengan mengolonisasi daerah rizosfer dan selanjutnya menginvasi lapisan dangkal korteks akar, sehingga ruang bagi patogen berkurang sehingga serapan unsur hara tidak terganggu dan pertumbuhan tanaman menjadi baik. Perbedaan tinggi tanaman disebabkan karena adanya perbedaan dosis Trichoderma sp. yang diaplikasikan.

\section{Jumlah Daun}

Hasil analisa sidik ragam menunjukkan bahwa terdapat interaksi antara perlakuan dosis dan interval waktu aplikasi Trichoderma sp. terhadap jumlah daun pada umur 55 hst. Selanjutnya dapat dilihat pada Tabel 2.

Tabel 2. Rata-rata Jumlah Daun Pada Umur 55 Hst.

\begin{tabular}{lc}
\hline \multicolumn{1}{c}{ Perlakuan } & Rata-rata Jumlah Daun Umur 55 Hst \\
\hline Dosis Trichoderma sp. $0 \mathrm{mg} /$ tanaman + interval 5 hari & $69.90 \mathrm{~d}$ \\
Dosis Trichoderma sp. $0 \mathrm{mg} /$ tanaman + interval 10 hari & $70.50 \mathrm{~d}$ \\
Dosis Trichoderma sp. $0 \mathrm{mg} /$ tanaman + interval 15 hari & $70.70 \mathrm{~d}$ \\
Dosis Trichoderma sp. $20 \mathrm{mg} /$ tanaman + interval 5 hari & $74.30 \mathrm{~cd}$ \\
Dosis Trichoderma sp. $20 \mathrm{mg} /$ tanaman + interval 10 hari & $79.70 \mathrm{bc}$ \\
Dosis Trichoderma sp. $20 \mathrm{mg} /$ tanaman + interval 15 hari & $80.47 \mathrm{bc}$ \\
Dosis Trichoderma sp. $40 \mathrm{mg} /$ tanaman + interval 5 hari & $87.70 \mathrm{a}$ \\
Dosis Trichoderma sp. $40 \mathrm{mg} /$ tanaman + interval 10 hari & $82.43 \mathrm{ab}$ \\
Dosis Trichoderma sp. $40 \mathrm{mg} /$ tanaman + interval 15 hari & $80.13 \mathrm{bc}$ \\
\hline
\end{tabular}

BNT 5\%

4,33

Keterangan : Angka-angka yang diikuti oleh huruf yang sama dalam kolom yang sama tidak berbeda nyata dengan

uji BNT

5

Pada tabel 2, dapat dilihat bahwa

pengamatan parameter jumlah daun menunjukkan kombinasi perlakuan dosis dam interval waktu terbaik terdapat pada perlakuan dosis $40 \mathrm{mg} /$ tanaman dan interval waktu aplikasi 5 hari sekali dengan nilai 78,67 pada pengamatan umur 55 hst. Hal ini disebabkan karena jamur Trichoderma sp. yang telah diberikan dapat membantu tanaman mempercepat proses terbentuknya buah serta meningkatkan jumlah daun dan diameter batang tanaman kedelai, sedangkan pada tanaman selada pemberian jamur Trichoderma sp. dapat meningkatkan jumlah akar dan daun menjadi lebih lebar. Peranan Trichoderma sp. yang diaplikasikan pada tingkat tertentu belum memberikan pengaruh yang nyata terhadap pertumbuhan dan jumlah daun tanaman kedelai. Menurut Dewi (2007), Trichoderma sp. dapat menaikkan luas permukaan pengisapan sistem perakaran sehingga dapat memacu pertumbuhan daun dan lebar diameter batang. Pemberian jamur Trichoderma sp. mampu membantu pertumbuhan tanaman kedelai menjadi lebih baik. Hubungan antara jamur Trichoderma sp. dengan akar tanaman kedelai merupakan simbiosis mutualisme, di 
mana tanaman mendapat keuntungan dalam hal pertumbuhan maupun pengendalian penyakit sedangkan Trichoderma sp. diuntungkan karena dapat menyerap nutrisi yang dihasilkan oleh tanaman.

Jamur Trichoderma sp. yang diaplikasikan kedalam tanah dapat berasosiasi dengan akar tanaman dan menyelimuti akar yang kemudian masuk kedalam perakaran tanaman melalui rambut akar dan menginfeksi akar dengan cara masuk kedalam bagian akar dan menyebabkan selnya membentuk bintil sehingga jumlah sel di dalam bintil akar meningkat. Akar yang terinfeksi Trichoderma sp. mampu membentuk akar-akar baru yang

Tabel 3. Rata-rata berat brangkasan basah

\begin{tabular}{cc}
\hline Perlakuan & Rata-rata berat brangkasan basah \\
\hline Dosis Trichoderma sp.0 mg/tanaman & $412,37 \mathrm{c}$ \\
Dosis Trichoderma sp. $20 \mathrm{mg} /$ tanaman & $423,87 \mathrm{~b}$ \\
Dosis Trichoderma sp. $40 \mathrm{mg} /$ tanaman & $427,07 \mathrm{a}$ \\
\hline BNT $5 \%$ & 2,09 \\
\hline
\end{tabular}

Keterangan :Angka-angkayang diikutioleh huruf yang sama dalam kolom yang samatidak berbeda nyata dengan uji BNT $5 \%$.

Pada tabel 3, dapat dilihat bahwa pengamatan parameter berat brangkasan basah menunjukkan perbedaan nyata pada level pemberian dosis terbaik terdapat pada perlakuan dosis $40 \mathrm{mg} /$ tanaman dengan nilai 427,07 . Hal ini diduga bahwa pemberian jamur Trichoderma sp. yang diaplikasikan kedalam tanah akan memberi dampak positif pada keberlangsungan pertumbuhan tanaman. Selain faktor eksternal dari kebutuhan air, cahaya matahari dan komponen lainnya peran akar sebagai sistem yang mengabsorpsi nutrisi hara dari tanah perlu memiliki jangkauan yang lebar. Sehingga nantinya dapat menyerap nutrisi yang lebih maksimal. Penyerapan yang lebar nantinya dapat memperbanyak nutrisi yang didapatkan. Selain itu perakaran yang lebar dan kuat dapat menahan dan menahan tanaman kedelai dari hempasan angin. Pengaplikasian jamur Trichoderma sp. ke tanah akan membentuk cabang-cabang baru pada akar tanaman.

Perakaran yang banyak tersebut dapat membantu penyerapan unsur hara menjadi lebih banyak dari pada yang tidak terinfeksi. Perakaran yang banyak tersebut dapat membantu penyerapan unsur hara menjadi lebih baik, sehingga tanaman dapat tumbuh dengan baik. Hasil penyerapan unsur hara diedarkan ke seluruh organ tanaman yang digunakan untuk proses fisiologi maupun pertumbuhan tanaman.

\section{Berat Brangkasan Basah}

Hasil analisa sidik ragam menunjukkan bahwa perlakuan macam dosis Trichoderma sp. terdapat pengaruh perbedaan nyata pada parameter berat brangkasan basah. Selanjutnya dapat dilihat pada Tabel 3. lebih baik, sehingga tanaman dapat tumbuh dengan maksimal. Hasil dari penyerapan unsur hara didistribusikan ke seluruh bagian tanaman yang digunakan untuk proses fisiologi maupun pertumbuhan tanaman. Pernyataan tersebut didukung oleh Fatimah \& Handarto (2008) yang mengatakan bahwa peningkatan jumlah daun dan tinggi tanaman sangat dipengaruhi oleh unsur $\mathrm{N}, \mathrm{P}$, dan $\mathrm{K}$ selain faktor lingkungan seperti suhu dan cahaya. Hal ini sesuai dengan fungsi ketiga unsur tersebut bagi tanaman yaitu dapat memacu pertumbuhan.

Trichoderma sp. memiliki sifat mikroparasit yang berarti dapat menekan perkembangan pathogen-patogen sebelum menjadi penyakit serta memiliki ketahanan yang besar terhadap infeksi yang ditimbulkan oleh pathogen. Selain itu, pemberian jamur Trichoderma sp. dapat mempercepat tanaman berbuah serta meningkat jumlah daun dan diameter batang pada tanaman kedelai, serta dapat melebarkan daun dan meningkatkan jumlah akar pada tanaman selada. 
Hasil analisa sidik ragam menunjukkan bahwa perlakuan macam dosis Trichoderma sp. terdapat adanya pengaruh

Tabel 4. Rata-rata berat brangkasan kering

\begin{tabular}{cc}
\hline Perlakuan & Rata-rata berat brangkasan kering \\
\hline Dosis Trichoderma sp. $0 \mathrm{mg} /$ tanaman & $96.60 \mathrm{c}$ \\
Dosis Trichoderma sp. $20 \mathrm{mg} /$ tanaman & $106.00 \mathrm{~b}$ \\
Dosis Trichoderma sp. $40 \mathrm{mg} /$ tanaman & $109.73 \mathrm{a}$ \\
\hline BNT $5 \%$ & 1.82 \\
\hline
\end{tabular}

Keterangan:Angka-angkayang diikuti oleh hurufyang sama dalam kolom yang sama tidak berbeda nyata dengan uji BNT 5\%.

Pada tabel 4, menunjukkan bahwa hasil terbaik terdapat pada perlakuan dosis 40 $\mathrm{mg} /$ tanaman dengan nilai 109.73 gram. Hal ini diduga pemberian jamur Trichoderma sp. mampu meningkatkan produksi tanaman kedelai melalui rangsang yang terdapat pada bagian akar sehingga jangkauan akar menjadi lebih luas serta mampu menyerap unsur hara leih banyak. Didukung oleh pendapat oleh Maryeni dan Hervani (2008) bahwa kepadatan dan perkembangan spora mikoriza secara positif berkorelasi dengan pengkolonian akar, sehingga penyerapan unsur hara lebih baik dan mampu mendukung pertumbuhan tanaman. Perkembangan perakaran yang baik menunjukkan peningkatan pada berat basah

\section{Berat Biji Per Petak}

Hasil analisa sidik ragam menunjukkan bahwa perlakuan macam interval waktu aplikasi Trichoderma sp. terdapat adanya pengaruh perbedaan nyata perbedaan nyata pada parameter berat brangkasan kering. Selanjutnya dapat dilihat pada Tabel 4. akar dan berat kering akar, karena penyerapan unsur hara yang tinggi dapat diketahui dari tingginya nilai berat basah dan berat kering akar serta pertumbuhan tanaman. Pertumbuhan vegetatif tanaman itu sendiri berpengaruh terhadap peningkatan berat kering akar, tinggi tanaman dan jumlah daun. Agen hayati yang menginfeksi akar menunjukkan pertumbuhan tanaman yang lebih baik bila dibandingkan dengan tanaman yang tidak terinfeksi agens hayati, sehingga proses fotosintesis yang berlangsung akan optimal. Melalui penongkolan akar oleh Trichoderma sp. mampu meningkakan ukuran dan berat tanaman kedelai.

pada terhadap parameter berat biji per petak. Selanjutnya dapat dilihat pada Tabel 5.

Tabel 5. Rata-rata berat biji per petak

\begin{tabular}{lc}
\hline \multicolumn{1}{c}{ Perlakuan } & Rata-rata berat biji per petak \\
\hline Interval waktu 5 hari & 443,10 a \\
Interval waktu 10 hari & $431,67 \mathrm{c}$ \\
Interval waktu 15 hari & $440,90 \mathrm{~b}$ \\
\hline BNT 5\% & 21,92 \\
\hline Keterangan : Angka-angka yang diikuti oleh huruf yang sama dalam kolom yang sama tidak berbeda \\
nyata dengan uji BNT 5\%.
\end{tabular}

Pada tabel 5, menunjukkan bahwa hasil terbaik terdapat pada perlakuan interval waktu 5 hari dengan nilai 443,10. Hal ini diduga pengaplikasian Trichoderma sp. secara kontinyu dapat mempercepat perkembangan akar, sehingga akar dapat lebih optimal dalam penyerapan nutrisi di tanah. Penyerapan yang optimal tersebut dapat memacu produksi buah pada tanaman kedelai serta mengurangi kelainan atau cacat pada saat proses pematangan buah. Pemupukan yang dilakukan secara intens dapat mengurangi tanaman dari krisis unsur hara karena kebutuhan hara akan terus tercukupi, secara tidak langsung juga semakin banyak Trichoderma sp. yang berperan dalam meningkatkan kesuburan 
tanah. Hal ini berpengaruh baik terhadap berat kering biji kedelai.

Menurut Sutanto (2002), Trichoderma

sp. merupakan mikroba tanah yang mempunyai peran dalam meningkatkan kesuburan tanah, membuat hara tersedia bagi tanaman serta berperan dalam memperbaiki struktur tanah. Trichoderma sp. juga

\section{Berat 1000 Biji}

Hasil analisa sidik ragam menunjukkan bahwa adanya perbedaan nyata pada perlakuan macam dosis Trichoderma sp. terhadap parameter berat

Tabel 6. Rata-rata berat 1000 biji

\begin{tabular}{cc}
\hline Perlakuan & Rata-rata berat $1000 \mathrm{biji}$ \\
\hline Dosis Trichoderma sp. $0 \mathrm{mg} /$ tanaman & $414.13 \mathrm{~b}$ \\
Dosis Trichoderma sp. $20 \mathrm{mg} / \operatorname{tanaman}$ & $434.50 \mathrm{a}$ \\
Dosis Trichoderma sp. $40 \mathrm{mg} /$ tanaman & $437.67 \mathrm{a}$ \\
\hline BNT 5\% & 1.82 \\
\hline
\end{tabular}

Keterangan : Angka-angka yang diikuti oleh huruf yang sama dalam kolom yang sama tidak berbeda nyata dengan uji BNT 5\%

Pada tabel 6, menunjukkan bahwa hasil terbaik terdapat pada perlakuan dosis 40 $\mathrm{mg} /$ tanaman dengan nilai 437,67. Hal ini diduga pemberian jamur Trichoderma sp. yang diberikan dapat membantu mempercepat pertumbuhan diameter batang tanaman kedelai sehingga tanaman dapat tumbuh dengan baik.

Trichoderma sp. juga memproduksi hormon auksin berupa IAA (Indole Asetic Acid) yang berfungi dalam pemanjangan sel-sel akar yang menyebabkan penyerapan nutrisi hara semakin tinggi. Penyerapan hara yang tinggi dapat mendukung pertumbuhan tanaman karena nutrisi tanaman tercukupi, sehingga mampu meningkatkan produksi tanaman (Contreras-Cornejo, 2009). Pemberian jamur Trichoderma sp. juga berpengaruh sangat nyata pada berbagai takaran perlakuan diduga karena jamur Trichoderma sp. dapat menginfeksi akar tanaman dan berasosiasi dengan akar sehingga proses penyerapan menjadi lancar dengan kebutuhan unsur hara yang cukup maka kapasitas nutrisi pada fase generatif khususnya untuk pematangan buah dapat terpenuhi. Proses tersebut merupakan akibat dari akar yang membentuk cabang akar yang lebih banyak dengan bantuan cabang menghasilkan hormon auksin berupa IAA (Indole Asetic Acid) yang berperan dalam pemanjangan sel-sel akar yang menyebabkan serapan hara semakin tinggi. Pertumbuhan tanaman dipengaruhi oleh serapan hara yang tinggi karena nutrisi tanaman dapat terpenuhi, sehingga produksi tanaman juga semakin tinggi (Contreras-Cornejo, 2009).

1000 biji. Selanjutnya dapat dilihat pada Tabel 6. akar tersebut.

Trichoderma sp. merupakan cara alternatif dalam mengembalikan unsur hara tanah yang hilang akibat penggunaan pupuk berbahan kimia, mempercepat proses pengomposan dan menjaga kesuburan tanah serta melindungi keberadaan mikroba yang tetap hidup dan aktif di dalam kompos. Trichoderma sp. memiliki multi fungsi yaitu selain sebagai organisme agen hayati juga berfungsi sebagai pengurai dan pemercepat proses pertumbuhan tanaman serta memberi dampak baik terhadap tanah, pertumbuhan tanaman dan hasil produksi tanaman.

\section{KESIMPULAN}

Dari hasil penelitian yang telah dilakukan pada perlakuan macam dosis dan interval waktu aplikasi Trichoderma sp. terhadap produksi tanaman kedelai (Glycine max L.) dapat disimpulkan bahwa :

Menunjukkan interaksi antara perlakuan macam dosis dan interval waktu aplikasi Trichoderma sp. terhadap parameter tinggi tanaman dan jumlah daun.

Menunjukkan pengaruh nyata pada perlakuan macam dosis Trichoderma sp. terhadap tinggi tanaman umur 25, 35, 45 hst 
dan jumlah daun pada umur 25, 35, 45 dan 55 hst.

Menunjukkan pengaruh nyata pada perlakuan macam interval waktu aplikasi Trichoderma sp. terhadap parameter berat biji per petak

Perlakuan dosis Trichoderma sp. 40 $\mathrm{mg} /$ tanaman dan interval waktu aplikasi 5 hari sekali menghasilkan nilai yang lebih baik dibandingkan perlakuan lainnya.

\section{SARAN}

Penelitian ini dapat dilanjutkan dengan perlakuan macam varietas kedelai dan perlakuan lainnya baik dosis Trichoderma sp. maupun interval waktu aplikasi dilahan sawah untuk lokasi yang berbeda, sehingga dapat mengetahui hasil yang lebih baik lagi.

\section{DAFTAR PUSTAKA}

Bakhtiar, Taufan, Hidayat, dan Y. Jufri. 2014. Keragaan pertumbuhan dan komponen hasil beberapa varietas unggul kedelai di Aceh Besar. Universitas Syiah Kuala, Aceh. Jurnal Floratek., 2(9): 46-52.

Castro, O. R.H. A., Cornejo, C, L., Rodriguez. M \& J. Bucio. L. 2009. The role of microbial signals in plant growth ang development. Plant signaling \& Behavior. 4:8, $701-712$.

Cornejo, C. H. A., L. Marcias- Rodrigues, C. Cortes-Penagos, and J.Lopez-Bucio 2009. Trichoderma virens, a Plant Benefecial Fungus, Enhances Boimass Production and Promotes Lateral Root Growth Through an Auxin-Dependent Mechanism in Arabidopsis. Plant Physiol; 149 (3): 1579 - 1592.

Dewi, A. I. R. 2007. Peran, Prospek Dan

Kendala dalam Pemanfaatan
Endomikoriza. Jurusan
$\begin{aligned} & \text { Budidaya } \\ & \text { Pertanian Universitas } \\ & \text { Bandung. }\end{aligned}$

Fatimah, S dan B.M. Handarto. 2008. Pengaruh komposisi media tanam terhadap pertumbuhan dan hasil tanaman sambiloto (Andrographis paniculata, Nees). Jurnal Embryo. 2 (5): 133-148.

Ismail, N dan T, Andi. 2011. Potensi Agens Hayati Trichoderma sp Sebagai Pengendali Hayati. BPTP Sulawesi Utara.

Marianah, L. 2013. Analisa pemberian Trichoderma sp. terhadap pertumbuhan kedelai. Balai Pelatihan Pertanian Jambi

Maryeni, R dan D. Hervani. 2008. Pengaruh mikoriza arbuskula terhadap pertumbuhan tanaman selasih (Ocinum sanctum. L). Jurnal Akta Agrosia 11(1): 712.

Mursidah. 2017. Perkembangan Produksi Kedelai Nasional dan Upaya Pengembangannya (Lanjutan) Di Propinsi Kalimantan Timur. Fakultas Pertanian, J. Univ. Mulawarman, Samarinda. 6(3):2234.

Sutanto, R. 2002. Penerapan Pertanian Organic, Permasyarakatan dan Pengembangannya. Kanisius. Yoyakarta.

Utomo, Budi. 2009. Pemanfaatan Beberapa Bioaktivator Terhadap Laju Dekomposisi Tanah Gambut dan Pertumbuhan Gmelina arborea Roxb. 